\title{
ON THE SEASONAL ABUNDANCE OF YOUNG FISH. IX. THE YEAR I 947
}

\author{
By P. G. Corbin, B.A. \\ Zoologist at the Plymouth Laboratory
}

(Text-figs. I-3)

The 1947 records of the seasonal abundance of the pelagic young stages of teleosteans in the plankton of Plymouth off-shore waters are a continuation of the series of observations made by Mr F. S. Russell (1930-47). The form of the previous reports is retained. The dates on which collections were made are given in Table I, and the monthly average catches of young fish in Table II. The fortnightly averages of all young fish less clupeids are shown in Fig. I, together with the corresponding curve for the period 1930-34.

I 947 was the first year since the war in which collections were made throughout the twelve months. It is relevant, therefore, to relate the 1947 records to the interrupted observations of the years 1939 and 1946. Describing the conditions of 1939, Russell (1940) states that '...the year 1939 has been the worst yet recorded and sets a new low limit to the production of fish'. As a result of the break in observations due to the war, he says ' ... we may never know what point the trough of the decline may reach'. Reporting on the 1946 records after the resumption of observations, he writes 'The 1946 collections were started too late to include the main period of abundance of young fish resulting from the spring spawners, but they afford evidence that as regards the summer spawners at any rate there is no significant change from the conditions existing in 1939. We cannot say what the conditions have been during the intervening years, but analyses of phosphorus content of the water during each winter in the period 1939-46 tend to show that conditions have remained much the same as they are at present, and that it is unlikely that there has been any large incursion of rich water characterized by Sagitta elegans which supports a large population of young fish.' (Russell, 1947.)

In 1947 , the total of all species of young fish was the lowest recorded since the observations started. All summer spawners were extremely scarce. Spring spawners were present in only slightly greater numbers, occurring mainly in two very small peaks in the second half of February and the second half of May. Gadus luscus and Chirolophis galerita contributed chiefly to the February peak, while the May peak was largely due to Gadus merlangus and Callionymus spp. It is of interest to record the occurrence of small numbers of young plaice, Pleuronectes platessa, in February. The young stages of this species were first taken in the Plymouth collections, also in small numbers, in 


\section{Table I. Dates on Which Collections Were made, I947}

All 2 miles east of Eddystone, unless otherwise stated

Jan. Feb. Mar. Apr. May June July Aug. Sept. Oct. Nov. Dec.

$\begin{array}{rrrrrrrrrrrr}29 & 2 & 6 & 3 & 23 & 2 & 7 & \text { II } & \text { I } & 6 & \text { I3 } & 3 \\ \ldots & \text { IO } & \text { I2 } & 8 & 27 & \text { I6 } & \text { I4 } & \text { I8 } & \text { I0 } & \text { I3 } & \text { I9 } & \text { I0* } \\ \ldots & \text { I7 } & \text { I7 } & 17 & 29 & 24 & 22 & 25 & 29 & 21 & 25 & \text { 19 } \\ \ldots & 27 & \ldots & 25 & \ldots & \ldots & 28 & \ldots & \ldots & 27 & \ldots & 22 \\ \ldots & \ldots & \ldots & \ldots & \ldots & \ldots & \ldots & \ldots & \ldots & \ldots & \ldots & 29\end{array}$

* Station E I.

Table II. Monthly Average Catches of Post-larvae per Half-Hour Oblique hauls with $2 \mathrm{~m}$. ring-trawl, 1947

Total young fish Ditto, less Clupeids

All Clupeid spp.

Clupea harengus

Gadus pollachius

Gadus merlangus

Gadus minutus

Gadus luscus

Gadus callarius

Onos spp.

Molva molva

Merluccius merluccius

Raniceps raninus

Capros aper

Arnoglossus spp.

Arnoglossus spp.

Scophthalmus norvegicus

Zeugopterus punctatus

Zeugopterus unimaculatus

Pleuronectes platessa

Pleuronectes limanda

Pleuronectes flesus

Pleuronectes microcephalus

Solea vulgaris

Solea variegata

Solea lascaris

Solea lutea

Serranus cabrilla

Caranx trachurus

Mullus surmulletus

Morone labrax

Ammodytes spp.

Ammodytes lanceolatus

Cepola rubescens

Callionymus spp.

Labrus bergylta

Labrus mixtus

Ctenolabrus rupestris

Crenilabrus melops

Centrolabrus exoletus

Trachinus vipera

Scomber scombrus

Gobius spp.

Lebetus scorpioides

Blennius ocellaris

Blennius pholis

Blennius pholis

Blennius gattorugine

Agonus cataphractus

Trigla spp.

Cottus spp.

Liparis montagui

Lepadogaster bimaculatus

Lophius piscatorius

Pipe fish

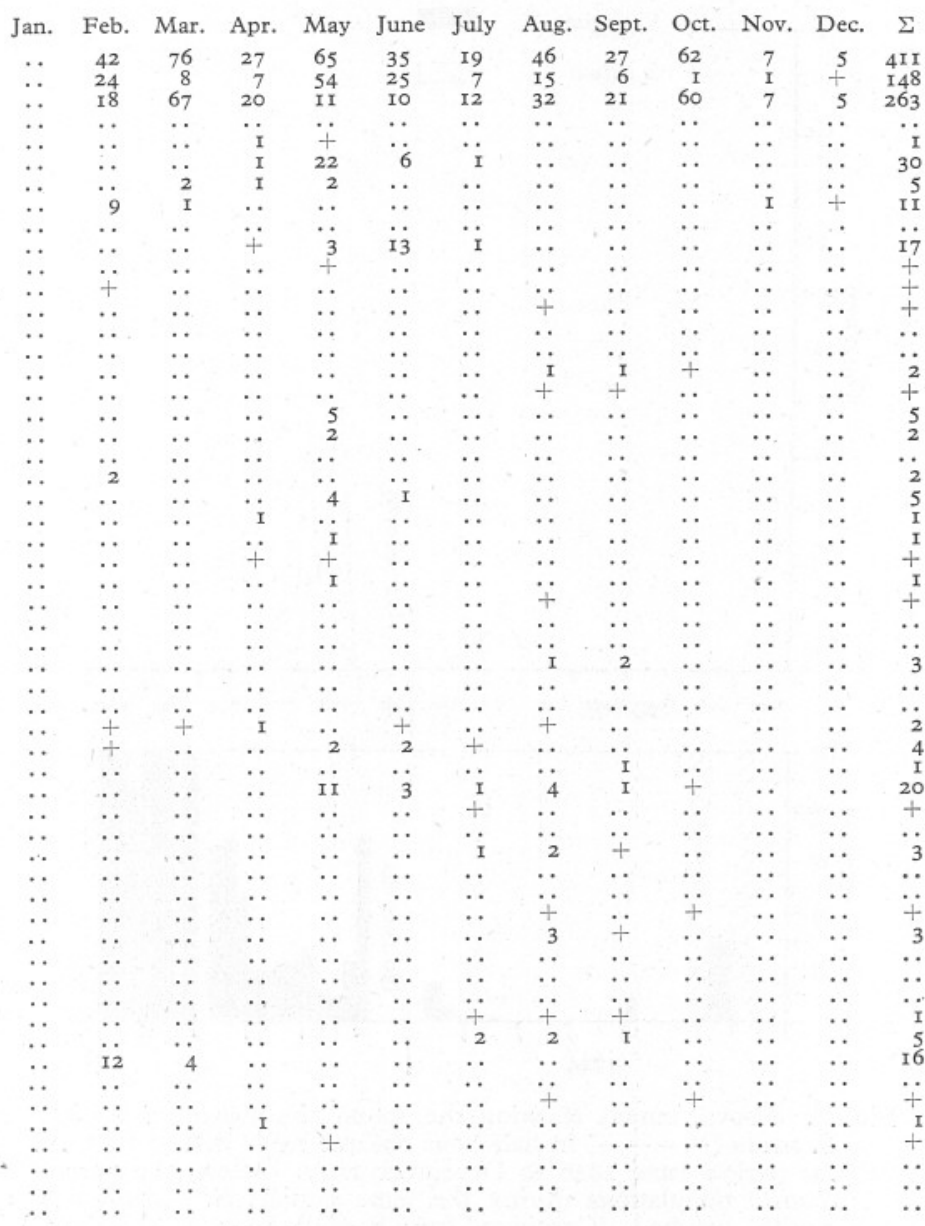




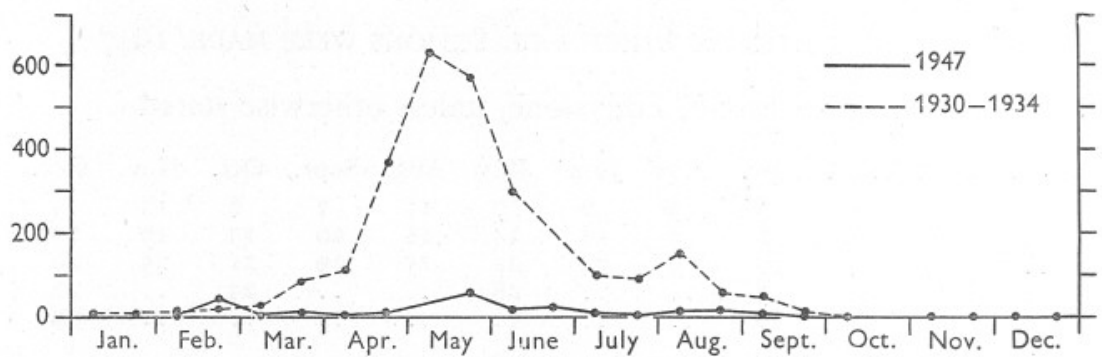

Fig. I. Curves showing the average catches in half-hour oblique hauls with the $2 \mathrm{~m}$. stramin ring-trawl for each fortnight for all young fish, excluding clupeids, in I947 (———-), and the same average over the period I930-34 inclusive $(----)$.

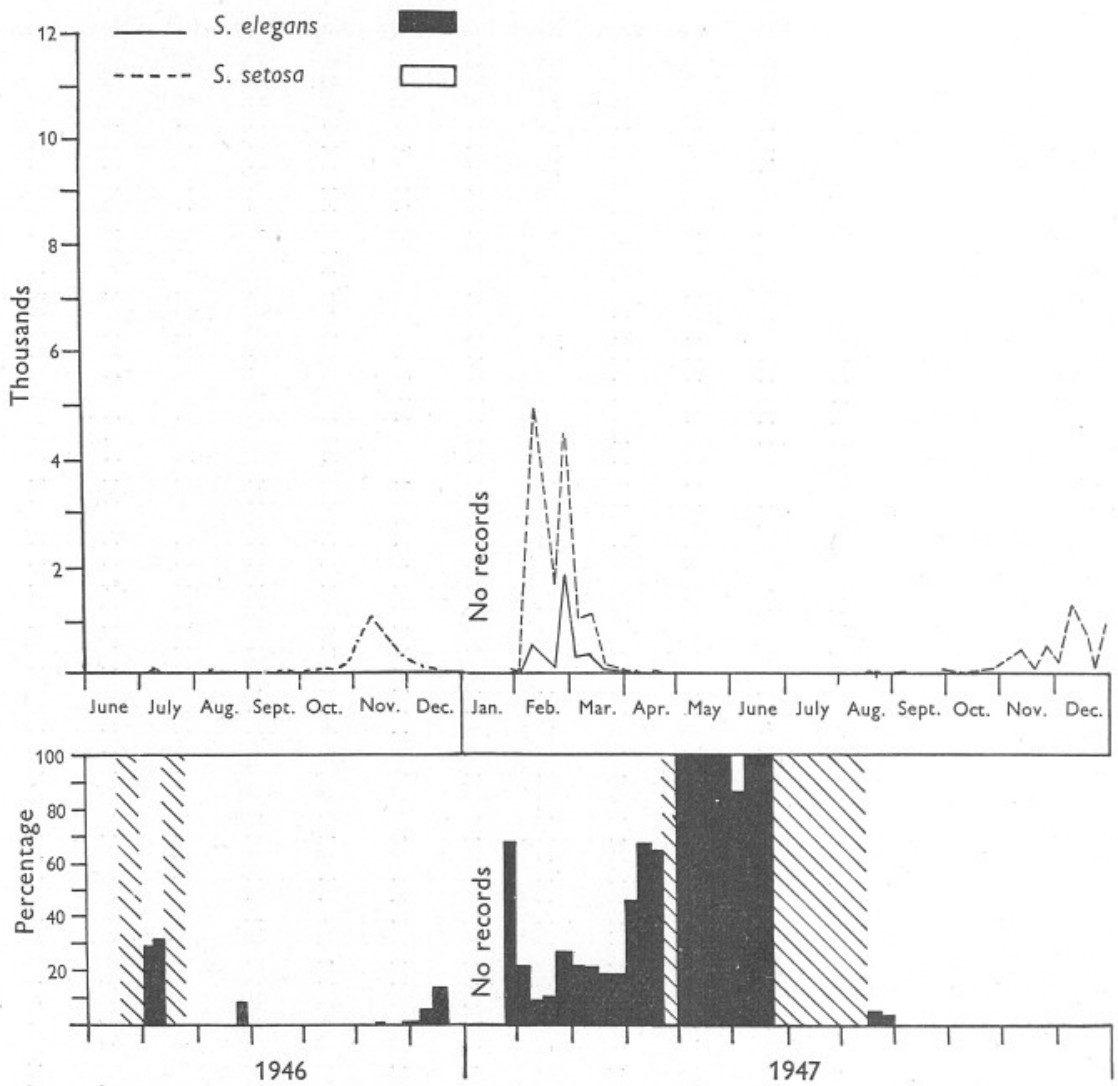

Fig. 2. Above, curves showing the actual abundance of Sagitta elegans $(-\longrightarrow)$ and $S$. setosa $(----)$ in half-hour oblique hauls with the $2 \mathrm{~m}$. stramin ring-trawl during the period June I946 to December I947. Below, the percentage composition of the Sagitta populations during the same period: S. elegans, black; S. setosa, white; no Sagitta, hatched. (Continued from Russell, I947, p. 607, fig. 2.) 
February and March, I939 (Russell, I940). Since then this low incidence has evidently been maintained in the area. None was, however, recorded in I946, as collecting was not resumed until June, well after the end of the spawning season of the plaice. The 1947 total (I403) of all species of young fish for the whole year was only I6\% greater than the 1946 total (I203) for the seven months period, June to December. It is only too evident that the decline in production of young fish continues without sign of recovery

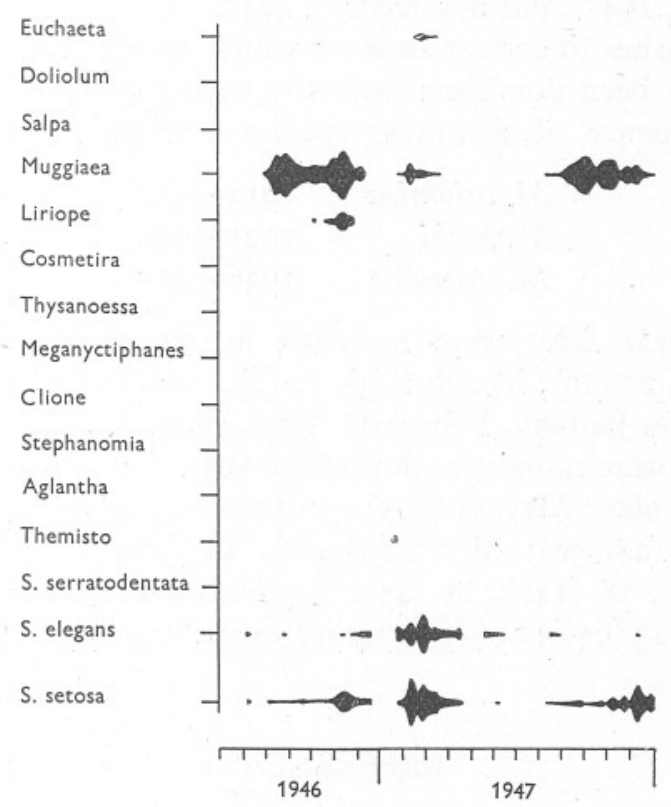

Fig. 3. Diagram showing the occurrence of the various plankton indicators in the collections off Plymouth during the period June 1946 to December 1947. The Muggiaea were all $M$. atlantica with the exception of a very few $M$. kochi, generally less than $\mathrm{I} \%$, which occurred during August and September, 1946. (Continued from Russell, 1947, p. 607, fig. 3.)

thus fully bearing out the observations of the incomplete year of 1946 and the deductions from the $1939-46$ winter phosphate data.

Plankton indicator species (Figs. 2, 3) showed no great change from the conditions of 1946 when there was a notable scarcity of plankton organisms. Sagitta setosa, although never numerous and almost completely absent during May-July, generally predominated over $S$. elegans. The high proportion of S. elegans in May and June (lower part of Fig. 2) was not in fact due to large catches of this species (upper part of Fig. 2); the maximum haul during this period contained only I7 specimens of $S$. elegans. In April the numbers of both species of Sagitta were similarly very low. 
Dr L. H. N. Cooper has kindly provided the information that phosphate values remained poor throughout the year. Towards the end of February, however, there was evidence of some richer water in the neighbourhood; the values at Eddystone were noticeably higher than those at E I, IO miles farther out, and the plankton catch was also richer.

Muggiaea atlantica was present in considerable though not exceptional numbers from January to March, and again from August to December; it was absent from April to July. M. kochi, which was present in small numbers in 1946 (Russell, I947), did not occur in 1947.

Mr Russell wishes to correct an error which occurred in this latter paper; $M$. atlantica has been dominant since the winter of 1936 , and not 1926 as given. The sequence of dominant species over past years is here summarized:

$$
\begin{array}{ll}
\text { M. atlantica } & \text { 1913-1924 } \\
\text { M. kochi } & 1925-1936 \\
\text { M. atlantica } & 1936-1947
\end{array}
$$

A few Euchaeta hebes were recorded in the early part of the year: February I7 (2), 27 (19); March 6 (3), I2 (I). Small numbers of Euphausian larvae occurred in January, February, April, June, August and November.

Pilchard eggs were numerous during the year. The following catches were made: April 25 (960); May 23 (405), 27 (I0,200), 29 (I2,700); June 2 (6450), I6 (I4,650), 24 (28,950); July 7 (I5,000), I4 (4600), 22 (4750), 28 (43); August II (580), I8 (I40), 25 (45); September I (4I), IO (680), 29 (65); October 6 (I72), I3 (650), 2 I (53), 27 (2); November I3 (I), 25 (4); December IO (5), $22(4)$.

\section{REFERENCES}

RusSELL, F. S., I930-47. On the seasonal abundance of young fish. I-VIII. Fourn. Mar. Biol. Assoc., Vols. xvI, pp. 707-22; xx, pp. I47-79 and pp. 595-604; XxI, pp. 679-86; xxII, pp. 493-500; XxIII, pp. 38I-6; XxIv, pp. 265-70; XxVI, pp. 605-8. 